\title{
The Role of Dayah Darul Mutaalimat Grong-Grong, Pidie District in Developing Santri
}

\author{
Ismail \\ Universitas Iskandar Muda, Aceh, Indonesia \\ ismailfisipol.unida@gmail.com
}

\section{Abstract}

This research related to the leader's task in fostering dayah education is carried out using a qualitative approach, in order to obtain comprehensive information about the role of dayah leaders in fostering students in Darul Mutaalimat Dayah. The role of leadership in the development of dayah education is by fostering students. The purpose of this study is to analyze the role of the leader of the Dayah Darul Mutaalimat Grong-Grong in fostering students and to analyze various obstacles both internal and external in the process of fostering students. The theoretical implications obtained that Dayah Darul Mutaalimat Grong-Grong in Pidie Regency, the learning process is a local wisdom and this system is still maintained, preserved as a traditional education model. While the practical implications of the researchers recommend that there is a need for government policy and support in order to foster dayah education. The results showed that the leadership of Dayah Darul Mutaalimat Grong-Grong in Pidie Regency had a very large role in the development of students, ranging from determining the curriculum studied until the implementation process to achieve the vision and mission of developing students based on absolute provisions governed by dayah leaders. Then the dominant internal and external factors become supporters and inhibitors of the formation of students in Darul Mutaalimat Dayah, among others, related to teaching staff (teachers), the availability of adequate dayah facilities, and good management of management. Internal factors supporting the development of Darul Mutaalimat Dayah santri existence of teungku / teachers who teach do not demand hard work and they voluntarily want to foster students, the availability of adequate dayah facilities, the realization of good harmony among fellow teachers, good management of dayah management and the location of the dayah which is very representative. The internal inhibiting factors in the formation of Darul Mutaalimat Dayah students are related to the inability of the dayah to provide training facilities through IT equipment, the capacity of the dormitory is still very limited and also the status of the dayah still private. the administration of education which is the operational legal basis for fostering santri.

Keywords

Roles; leaders; guiding santri

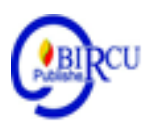

\section{Introduction}

After the independence of the Republic of Indonesia on August 17, 1945, the Government began to rebuild the formal education system, while the traditional education system persisted. The traditional education system in Aceh has partly undergone very drastic changes, and these changes are continuing because the shape and education system are still felt to have not met the expectations of the public. But there are still many dayah education 
systems whose implementation still adheres to the old curriculum that applies to traditional dayahs in the context of fostering santri.

In fostering santris tengku dayah or dayam leaders have a very large role to direct the vision and mission of dayah in fostering santri. The implementation of the direction of dayah education is the policy and the full decision of Dayah Darul Mutaalimat's leadership in coaching students. The word dayah comes from the words zawiyah which in Arabic means corner or corner. As an educational institution, the dayah indeed originated from recitals held in the corners of the mosque which were very early educational institutions in Islam.

Based on the studies at the corner of the mosque, the birth of an institution called zawiyah. In Aceh the term zawiyah eventually changes to dayah because it is influenced by the Acehnese language which basically has no $\mathrm{Z}$ sound and tends to be shorter. However, the words of zawiyah can still be found in the use of the dayah world. Dayah education in Pidie Regency is based on the values of human life that are based on Islamic teachings and are very closely related to the reality of social life in everyday society. Community trust in the teachings of Islam has a very sacred value while social reality has a belief that is relatively in accordance with its development.

As an Islamic educational institution, dayah contributes greatly in fostering students, especially in exploring the knowledge of Islam and practice it as a guide to daily life. Santri who have been trained by Dayah leaders Darul Mutaalimat are in charge of boarding or settling in asarama that has been provided by dayah leaders. The formation of Islamic boarding schools in the Unitary State of the Republic of Indonesia in general has received guidance from the Ministry of Religion of the Republic of Indonesia, whose guidance is still very poor when compared to general education and education in other madrassas. Pesantren education is only carried out by the community together with the owner and the pesantren teachers in each pesantren.

Empirical facts obtained through observations show that the life and death of a dayah are highly dependent on the management capabilities of the dayah leaders and the community. Guidance for santri is an effort that is done consciously, planned, directed, organized by the leadership of the dayah to improve one's knowledge and skills, carried out with guidance, teaching and supervision to achieve the expected goals.

\section{Review of Literature}

\subsection{Theory of Role}

Role theory is known as the role of theory, this is a theory that analyzes the tasks that must be carried out by people or institutions that have formal or informal positions. In the Indonesian dictionary, there are two terms that emerge namely role and role. The role is a set of levels that are expected to be owned by those in the community. The role is part of the main task that must be carried out. Selly in Salim (2014: 141) defines the role or role is "The function or position that the subject or expected to have an organization, in society or in relationship".

From the definition above, the role is constructed as a function or position of the subject in the organization and in relation to society. Function is equated with the position or work performed or the use of something. Mukti in Salim (2014: 142) role theory is "The theory that studies that society will behave according to status and role". Community behavior is a response or reaction that is manifested in movements (attitudes), but also body movements or speech in the community. So role theory is a theory that studies and analyzes 
the role of institutions and society in solving, solving and ending problems that arise in the life of society, nation and state.

Role theory put forward by Robert in Salim (2014: 143) role theory describes "Social interaction in the terminology of actors who are in accordance with what is determined by culture". In accordance with this theory, role expectations are shared understandings that lead us to behave in everyday life. According to this theory, someone who has a certain role, for example as a doctor, student, parent, woman and so on, is expected to have someone behave in accordance with that role. Likewise, Teugku dayah needs to foster students, because he is a leader who is brave enough to do that. So because of his status as a dayah leader, he must conduct coaching activities for students who live in their places and their behavior is determined by their social role.

The role referred to in this discussion is a set of behavior possessed by Tengku Dayah in fostering santri without expecting payment from santri, instead of making an effort to obtain assistance from the public, stakeholders and also from the government which is not binding. The phenomenon that has happened to Dayah Darul Mutaalimat has been the role of an excellent leader so that he has the support of various parties in fostering students.

\subsection{Organizational Theory}

Dayah is an organization engaged in the field of religion, in this case certainly the vision and mission of the dayah organization is more on fostering santri. God has created man to live on this earth not alone, as an individual because he is in the dimension of the natural environment, he naturally is in a society, and thus humans as individual creatures, because their existence must be able to position themselves as social creatures. Organizations have various meanings that are very varied, organizations can be seen as a container, process, behavior, and as a means to an end. Siagian in Daryanto (2015) defines organization as "a form of union between two or more people who work together for a common goal and are formally bound in a partnership, where there is a relationship between a person called the leader and a group of people called subordinates". While Henry in Daryanto (2015) organization is "a group of people who are formally bound to achieve goals".

Related to this, Bellon in Thoha (2014) states that organizational theory describes "Human behavior that starts from the form of tribes to complex government, while administrative theory describes human behavior in work groups". Mansengi (2013) organization is that "rational coordination of the activities of a number of people to achieve some clear goals through the division of labor, functions, and through levels of authority and responsibility". According to Agung (2014: 10) organization is "a pattern of relationships through which people under the direction of superiors pursue common goals and form every human union to achieve common goals and a system of cooperative activities carried out by two or more people".

Based on the description that has been explained above, it can be understood that in an organization, it must at least have, among others, the number of people who work together in this case, of course, tengku and also santri, the expected shared goals, in the form of learning and fostering interaction in conducting cooperation. These and interactions are intended to achieve common goals. 


\subsection{Leadership Theory}

Tengku dayah as a leader who has full power in carrying out the vision of the dayah mission to foster santri. Soekanto (2014: 318) states that leadership is "the ability to influence people who are led or followers, so that other people behave as desired by the leader".

Leadership as a position and leadership as a social process. As a position, leadership is a complex of rights and obligations that can be owned by a person or a body. As a social process, leadership includes all actions carried out by a person or a body that causes movement from the community. According to Syaukani (2013) leadership as "A group process carried out by someone in managing and inspiring a number of jobs to achieve organizational goals through the application of management techniques".

\subsection{Concept of Fostering Dayah Education}

Development of dayah education, consisting of three words namely Development, Education and Dayah. Coaching is an effort that is done consciously, planned, directed, regularly to improve one's knowledge and skills, carried out with guidance, direction and supervision to achieve the expected goals.

Whereas what is meant by Education according to Law No. 20 About the 2003 National Education System Article 1 paragraph 1 is a conscious and planned effort to create an atmosphere of learning and learning process so that students actively develop their potential to have religious spiritual strength, self-control, personality, intelligence, noble character and skills needed by himself, society, nation and country. Dayah is generally known only in Aceh.

The word dayah comes from the word zawiyah which in Arabic means the corner or corner of the mosque (Arabic Dictionary AW Munawir 1997). Dayah education is education that serves to prepare students to become members of the community who understand and are experts in the science of Islam which is held in Dayah / Islamic Boarding School with accommodation system (Aceh Qanun Number 5 Year 2008 Concerning Education Organization Article $23 \mathrm{C}$ ).

To review education development in dayah institutions in Aceh after the promulgation of Law No. 44 of 1999 concerning the Implementation of Special Privileges of the Province of Aceh and Law No. 11 of 2006 concerning the Government of Aceh and after the Government and Aceh Government policies on fostering dayah education in the Province Post-Tsunami Aceh in 2004, all elements of interest in the formulation of policies require a variety of comprehensive information about the existence, guidance and development of previous dayahs.

Development of dayah conducted by dayah leaders has received legality from the Government of Aceh through a variety of regulations made by the executive and also the III.

\section{Research Method}

This study uses qualitative methods to describe and analyze the role of dayah leaders in fostering dayah students. Bogdan in Sugiyono (2014) argues that qualitative research is "research conducted in natural conditions". According to Nawawi (2013: 64) qualitative methods can be interpreted as "problem solving procedures that are investigated by describing / describing the state of the subject / object of research (a person, institution, and also society) at the present time based on the facts that appear or as they are". 
Data collection techniques carried out through observation and interviews with various speakers. Then the data analysis is done using the opinion as stated by Moleong (2014), namely:

1. Perseverance Observation.

2. Data Triangulation.

3. Discussion with colleagues.

\section{Discussion}

This research was conducted to examine the role of Dayah Darul Mutaalimat GrongGrong leader in Pidie Regency in carrying out the task of fostering dantri. Dayah in carrying out guidance to students received support from the community, stakeholders and also from the government.

The results showed that with the support of various parties can facilitate the tengku dayah in providing guidance to students in accordance with the curriculum that applies to the dayah. In fostering Dayah Darul Mutaalimat Grong-Grong in Pidie Regency the learning process is a local wisdom and this system is still the norm in the formation of students. Then the results of the study also showed that there was government support in the form of policies, so that the leadership of Dayah Darul Mutaalimat Grong-Grong Pidie Regency had a very large role in the development of students, starting from determining the curriculum studied until the implementation process to achieve the vision and mission of guidance of students based on the provisions absolutely governed by the leadership of the dayah. The results of the study relate to supporting factors for the formation of students in Dayah Darul Mutaalimat, including the existence of teaching staff (Tengku), the availability of adequate dayah facilities, and good management of management. The inhibiting factor in the formation of Darul Mutaalimat Dayah santri is related to the inability of the dayah to provide training facilities through IT equipment, the capacity of the dormitory is still very limited and also the status of the dayah is still privately owned.

\section{Conclusion}

Based on the discussion as described above, it can be concluded that the role of leadership in the development of dayah education through guidance of students in Darah Mutaalimat Grong-Grong Dayah starting from the learning process that has been determined by the leadership and used as a standard model of traditional education, and supported by policies government. Dayah Leaders Darul Mutaalimat Grong-Grong Pidie Regency has a very large role in the development of students, ranging from determining the curriculum studied to the implementation process to achieve the vision and mission of building students based on absolute provisions governed by dayah leaders and cannot be contested by anyone . The supporting factors of Darul Mutaalimat Dayah santri are the existence of teungku / teachers who teach do not demand hard work payments and they voluntarily want to foster students, the availability of adequate dayah facilities, the realization of good harmony among fellow teachers and also fellow students, dayah management management good location and location of dayah that is very representative. Whereas the inhibiting factor in the formation of santri in Dayah Darul Mutaalimat is related to the inability of the dayah to provide coaching facilities through IT equipment, as well as the capacity of the dormitory which is still very 
limited and also the status of the dayah is still privately owned.legislature, making it easier for dayah leaders to conduct guidance for students.

\section{References}

Agung, Rosidah. (2014). Manajemen Sumber Daya Manusia: konsep, teori dan pengembangan dalam konteks organisasi publik. Yogyakarta: Graha Ilmu.

Daryanto (2015). Sosiologi Organisasi Suatu Pengantar. Jakarta: PT Raja Grafindo Persada.

Masengi. (2013). Kinerja Organisasi. Bandung: PT. Remaja Rosdakarya.

Moleong, Lexy. J. (2014). Metode Penelitian Kualitatif. Bandung: Remaja Rosdakarya.

Nawawi, Haidar. (2013). Metode Penelitian Bidang Sosial. Yogyakarta: Gajah Mada University Press.

Salim dan Nurbani. ES. (2014). Penerapan Teori Hukum Pada Penelitian Disertasi dan Tesis. Jakarta: PT. Raja Grafindo Persada.

Soekanto, Soerjono. (2014). Sosiologi Suatu Pengantar. Jakarta: PT. Raja Grafindo Persada.

Sugiyono. (2014). Metode Penelitian Kuantitatif Kualitatif dan $R \& D$. Cetakan ketujuh. Bandung: Alfabeta.

Syaukani. (2013). Pemimpin dalam organisasi. Bandung: Alfabeta.

Thoha, Miftah. (2014). Birokrasi Pemeritahan Indonesi di Era Reformasi. Yogyakarta: Media Widya Mandala. 